\title{
Five Easy Pieces: Legitimation at Work in Cases Related to Energy Transitions
}

\author{
Siddharth Sareen
}

\begin{abstract}
This chapter provides an overview of five energy transition cases by describing the questions posed to five authors to guide the flow of argument in their chapters and summarising case treatments with respect to accountability and legitimation. It links four proposed practices of legitimation with analytical takes on wide-ranging cases. The cases span urban energy transitions over time and space in Germany, forest and land conflicts over authority in Indonesia, urban climate targets based on carbon metrics in Norway, the modalities of Nordic electric mobility transitions, and biodiversity conservation and energy extraction in the USA. Pinpointing the relevance of each case to legitimation, this chapter explicates how questions of accountability are germane to how the energy transitions associated with these cases impact sustainability.
\end{abstract}

Keywords Accountability $\bullet$ Crisis $\bullet$ Energy transitions $\bullet$ Legitimacy $\bullet$ Sustainability

\footnotetext{
S. Sareen $(\bowtie)$

Department of Geography, Centre for Climate and Energy Transformation, University of Bergen, Bergen, Norway e-mail: Siddharth.Sareen@uib.no

(C) The Author(s) 2020

S. Sareen (ed.), Enabling Sustainable Energy Transitions, https://doi.org/10.1007/978-3-030-26891-6_3
} 
It is imperative that we bear in mind the deep variation in how energy transitions are experienced by different actors, and that their ability to exercise their stakes in the outcomes differs by orders of magnitude. Part I reframed energy transitions as a response to accountability crises, deconstructed accountability into practices of legitimation and presented a typology of those practices. The cases in Part II surface a number of complex spatiotemporal conjunctures and deconstruct the climate and energy crises entangled therein.

If even privileged academics at Global North institutions, wellresourced and relatively free to choose our own research themes, were to shy away from attempts to mobilise knowledge to inform and steer action and hold power accountable, it would spell little hope for sustainable futures. These cases, and the collaborative project ensconcing them, constitute an argument that we can in fact make a meaningful difference, that we have a crucial role to play in making energy transitions accountable and directed towards sustainable outcomes. This is our contribution to make in addressing the climate crisis for those at risk today to have livable futures.

Accordingly, this middle section of the book provides short overviews of cases relevant to energy transitions in a variety of sectors and regions, with a focus on legitimation and accountability in the governance of environmental change. Each of the five chapters is authored by an accomplished environmental governance scholar working on energy transition cases and kindred subjects. Each has reframed their work on a particular case in terms of crises of accountability and practices of legitimation. The following questions guide their independently composed individual responses and constitute a general flow of argument:

- What is the case and why is it an energy transitions case?

- What crises of accountability are being maintained or challenged?

- How do environmental governance scholars characterise the case?

- What practices of legitimation appear to be at play in empirical work?

- What interventions could enable sustainable outcomes under transition?

Timothy Moss draws on the governance of urban energy infrastructure across time and space to unpack the changing relationship between energy transitions, accountability and practices of legitimation across the formidable range of contextual variation in Berlin over the past century. His historical analysis of accountability in the changing contexts that drove 
energy transitions in this city over the course of a century of political flux surfaces many potent concerns. Among these is the difficulty of evaluating past transitions in relation to sustainability, which only appeared in its familiar current form from the 1970s onwards and has gained notable attention beyond academia even more recently, mainly in the twenty-first century. He also foregrounds that accountability crises are not a new concern but rather have deep roots. What is new, in this sense, is the relevance of sustainability as a concern linked with energy transitions, which directs our attention in this book to accountability crises that are only beginning to be sufficiently recognised. Moss' historical analysis of Berlin's energy transitions, moreover, emphasises the context specificity of accountability as relationally negotiated within a spatiotemporally shifting and historically contingent political economy.

Christian Lund probes a case of forest and land conflict that is, at base, about struggles over authority and accountability. He considers the generative potential of an accountability lens when applied to questions of land governance that remain under-addressed in energy transitions scholarship. In his handling, authority is relationally and reflexively construed, through active and tacit contestations between competing actors. Rather than a state and non-state binary, governance here revolves around questions of claims to statehood and their recognition at multiple scales. Citizens seek to have their claims met by recognising the state at the more local village scale rather than a distant central government and, in doing so, try to reconfigure relations of power and authority. Power is unequally distributed, but its legitimation is necessarily contingent, and is what bestows an organisation with institutional authority to control resources in more persistent ways that can subdue resistance. In Lund's telling, this contingency is revealed as an opportunity for hitherto marginalised actors to not only vye over resources but to orchestrate a redefinition of where authority resides, and thereby of the state itself.

Håvard Haarstad examines the problematic of setting targets for carbon emission reduction at the urban scale both in general and specifically in Norway in terms of its pitfalls as well as potential. He first sets up a case for debunking urban climate and energy targets as the vanity projects of street-smart local politicians- the targets do not seem to be achievable and policies to realise them are not systematically deployed. Then he takes a step back to point out that the very act of target-setting has performative and discursive power, it imbues actors with the ability to point at a goal and orchestrate ambitious actions around it that might otherwise have 
failed to get off the ground. This normalising of mitigation targets in various forms at the urban scale, in Haarstad's rendering, enables energy transitions. It does so by establishing new accountability relations in a graduated manner that imbricates them within existing routines of decision-making and configurations of power. For strategies to legitimate carbon reduction, discretion may well be the better part of confrontation in shifting policy-making over vital domains to the urban scale for implementation in line with climate target creep.

Benjamin Sovacool bases his reflections on engagement with electric vehicle roll-out in the five Nordic countries, a region that is in the global lead on this energy infrastructure and mobility decarbonisation transition. Drawing on an impressive range of empirical material, this case highlights the many urgent reasons for a shift to electric mobility. It engages closely with the materiality and political economic dynamics of how this transition actually pans out in order to throw into relief how electric mobility alone can hardly address the problems it is commonly portrayed as resolving; these problems are deeply embedded within systems of mobility themselves. Sovacool flags unfolding accountability crises linked with inequitable access to electric vehicles, exclusionary and elitist planning, global externalities, and exacerbated social vulnerabilities. The chapter problematises the perpetuation of car-centric mobility alongside planning centred on public transport electrification and points to the perils and promises of how roll-out interfaces with electric grid flexibility and the integration of renewable energy sources. His treatment spans sectoral actors from national authorities to vehicle dealerships and from those affected by extraction to those buying Teslas, in keeping with an appreciation of accountability relations as multi-scalar, multi-sited, polycentric and amorphous in a sectoral layering of regimes.

Steven Wolf thinks through a case of dysfunctional habitat exchange markets around the sage-grouse in Colorado to interrogate the construction of hollow accountability. On the one hand, science-based assessment presents energy extractive industries with clear costs associated with oil and gas extraction activities so as to compensate for the displacement of this endangered species by provisioning for habitat replacement. Institutional orchestration creates the requisite paraphernalia around this, including actors to execute compensatory habitat exchange, a quantification tool and a market to facilitate these transactions. On the other hand, power trumps substantive assessment, as the extractive majors refuse to entertain the estimated costs and the habitat exchange fails to record a 
single transaction. Wolf argues that these developments are rightly understood as situated within accompanying changes at the federal and state levels pertaining to regulation and political dynamics. Rather than a case of abject failure, he reads it as the construction of requisite institutions to exercise accountability mechanisms that render energy extraction and biodiversity conservation not necessarily mutually exclusive, given political will and future enabling policy. This cross-sectoral analysis raises questions of legitimacy for the evolution of the energy sector in the American West, evidencing a lack of credibility to claims of energy transition.

After the five case chapters comes Part III, which comprises editorial reflections and a co-authored concluding synthesis. It takes a step back to revisit the cases at a higher level of abstraction. Chapter 9 draws out the various registers where practices of legitimation are at work in each case. Chapter 10 demonstrates application of the practices of legitimation within dimensions that are present in the five cases and highlights opportunities to cross-fertilise scholarship on energy transitions and environmental governance. Part III thus brings together openings in the fields that are broached by the case chapters and by the framing of the book. With this in mind, the reader is invited into the wide-ranging world of energy transitions over the course of Chaps. 4, 5, 6, 7 and 8 .

Open Access This chapter is licensed under the terms of the Creative Commons Attribution 4.0 International License (http://creativecommons.org/licenses/ by $/ 4.0 /$ ), which permits use, sharing, adaptation, distribution and reproduction in any medium or format, as long as you give appropriate credit to the original author(s) and the source, provide a link to the Creative Commons licence and indicate if changes were made.

The images or other third party material in this chapter are included in the chapter's Creative Commons licence, unless indicated otherwise in a credit line to the material. If material is not included in the chapter's Creative Commons licence and your intended use is not permitted by statutory regulation or exceeds the permitted use, you will need to obtain permission directly from the copyright holder.

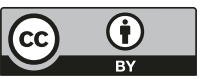

